\title{
Impact of Seawall Development to the Sulawesi Fishermen Community in Pambusuang Village
}

\author{
Muhammad Zulkifli ${ }^{1}$ \\ Email: kipli.imm@gmail.com \\ ${ }^{1}$ Ministry of Home Affairs, Indonesia
}

\begin{abstract}
A coastal protection structure mostly built to protect human from the destructive wind and wave energy. The various option of type and design has been invented in the development. This study investigates the impact of seawall development in Pambusuang Village, West Sulawesi. This study will examine the fishery activity change after the development of seawall. The benefit and disadvantages of the seawall structure to the community also as well as the community response to address the impact of seawall development will be explored in this study. A mix quantitate and qualitative approach is used in this study. A set of questionnaires has been distributed and structured interview to selected informant were also conducted. The study found that fishermen has changed their docking behavior due to the limited area to docking. Moreover, the respondent believes that seawall has properly function to halt erosion, protect their house and other infrastructure from the wave attack. The other issues is the disharmony between pro and contra seawall development, inundated river flow and damage of natural habitat. The response of the community to addressing some impact of the seawall development such as their adaptation to the sloping gate between the seawall, the use of traditional anti fouling painting and their suggestion to construct breakwater disattached from the shoreline. The findings above has been formed the basis of recommendations to have a participatory development approach and experience sharing between the parties in the community to adapt with the impact of seawall development.
\end{abstract}

Keywords: Coastal, Development, Village

Received: November 25, 2021

Revised: November 30, 2021

Accepted: December 10, 2021

\section{Introduction}

Coastal area has been recognized as part of natural resource with high diversity that very important for social, economy and cultural development as well as national sovereignity pillars. Coastal area over the word has been changing due to some factors that related to geological process. However, the trend of human civilization to live in the coastal area resulting effort to protect the coastal area from the erosion.

Human civilization has started the protection to coastal landscape since thousand years back, when Eastern Roman Empire built the wall along the coastline of constantinopel as a defense system but then the purpose has been shifted to a structures that can help safeguard against catastrophic and costly damage caused by hurricanes and other storms (Necipoğlu, 2001). Selvan. et al (2016) describe the effectiveness of the Pondichery Seawall to protect human settlement when the 2004 tsunami that attack shoutern and shouth east asia.

The discussion about seawalls continuously improved. One of the discussion is to find changing of environtment after the seawall development. Tarigan (2010) has published a research titled Observation and Change Analysis of Coastline in the Cisadane Coast, Banten Province. He found several abrasion and accretion areas that may caused by human activity or 
natural phenomena like high current and high wave during monsoon over that area. Development of hard structure to protect shoreline also has been analyzed by Fadlan (2015) .He conclude that breakwater generally contruct to decreace the impact of the tidal waves but on the other hand, this construction has been change the paralel shoreline to different wide of sediment on the side of the construction.

The main purpose of this study is to examine the impact of seawall development. The goal this of the study as follows; (1) To review the background of seawall development and the impact; (2) To identify the impact of seawall development; (3) To examine whether the impact of seawall development various according to the background of the community; (4) To identify the response of the community to the impact of seawall development

The scope of this study is to understand the concept of seawall development, the impact on the fishermen activity as well as the community responses to develpoment of seawall. Furthermore, the scope of this study will be narrowed to the social and physical impact of seawall development in Pambusuang Village. This research is an effort to provide a deep view of relationship of physical development to the social life.

\section{Study Area}

Pambusuang Village is one of village located in Balanipa subdistrict, Polewali Mandar Regency. Total area of Pambusuang Village is $5,93 \mathrm{~km}$ sq. The largest hamlet also called Pambusuang Hamlet. Topographical condition of Pambusuang village vary from coastal area, lowland and highland Pambusuang has the $788 \mathrm{~m}$ shoreline that support the fishery activity on that village. Most of the residential that cover more than a third of total area located in range $0-400 \mathrm{~m}$ from the shoreline. Total population of Pambusuang village is 5,420 people with household was around 1,237 with the average of houshold member was 4.3 people per household. Almost a-third of the population work as fishermen. 


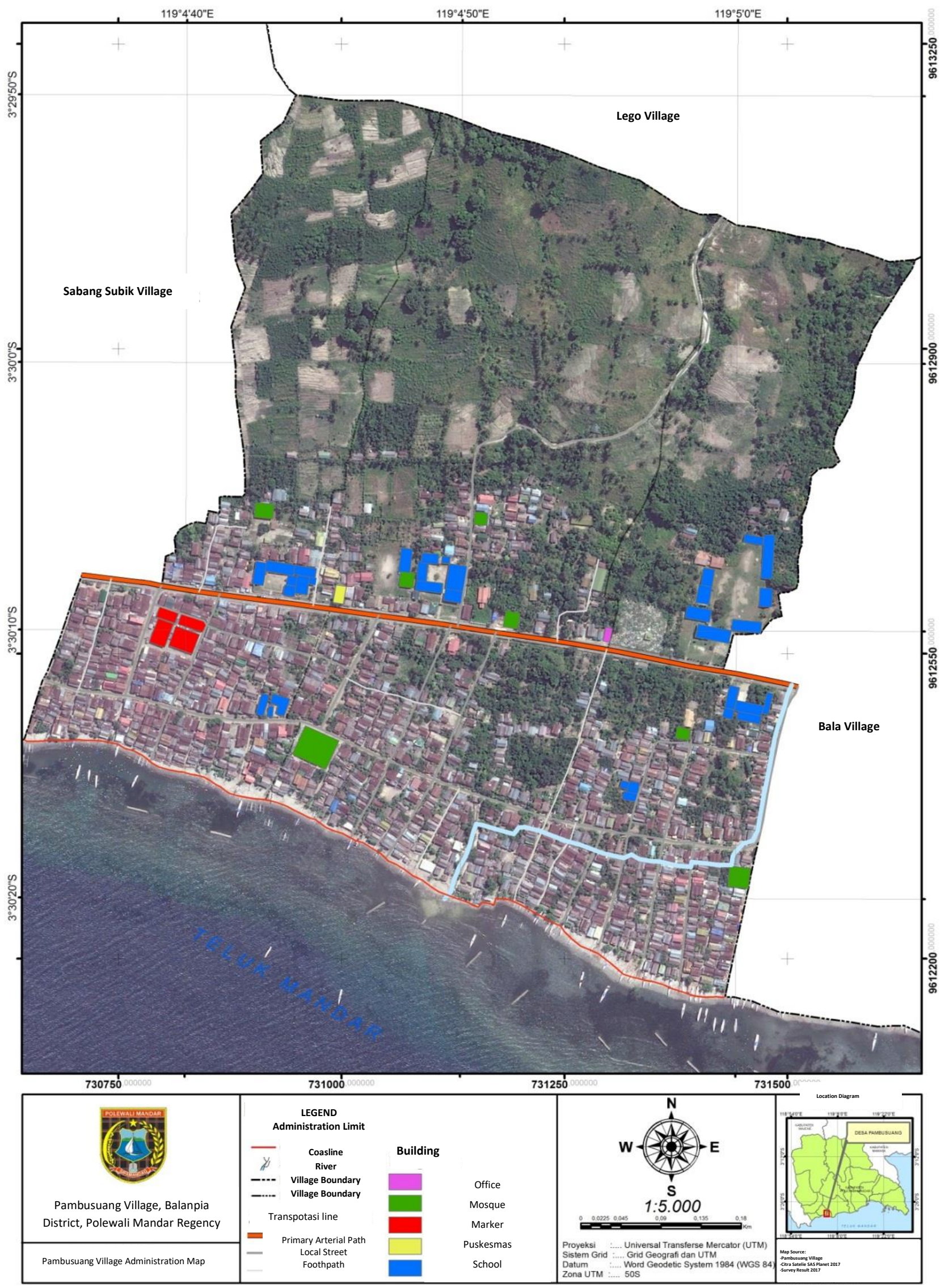

Figure 1. Pambusuang Village Map 


\section{Literature Review}

The focus on this study is one of the forms of hard structures of coastal protection which is seawalls. Seawall has been found effectively to protect everything behind the structure. Seawalls typically have a profound establishment for stability as well as to defeat the earth pressure on the landward side of the structure or earth anchors buried upland, are often connected to the wall by bars (Dean \& Dalrymple, 2002)

A standard technical definition of seawall can be seen as follows:

Seawalls are onshore structures with the principal function of preventing or alleviating overtopping and flooding of the land and the structures behind due to storm surges and waves. Seawalls are built parallel to the shoreline as a reinforcement of a part of the coastal profile (USAEC, 1995)

Seawalls may be vertical, sloping, stepped, or concave seaward and may be smooth or have projections on their faces. Baba and Thomas (1987) have suggested that: "A combination of a seawall and a frontal beach is a better coastal protective measure in the case of an equilibrium beach with cyclic erosional-accretional processes." because: the longshore bar formed during the peak erosional phase acts as a submerged breakwater. Higher energy waves break at the longshore bar permitting only low energy waves to reach the seawall directly."

Although many workers believe seawalls have little influence on the formation of beaches fronting therm the statement by Magoon and Edge (2001) on this subject is worthy note "but, they do not really stabilize the shoreline in any long-term sense. These structures are more related to storm protection than stabilizing the shoreline over the daily processes which are so important in shaping the beach." There is a need for seawalls and breakwaters to be tested in three-dimensional models with movable beds, in order that probable scour can be predicted. This does not overcome the need for monitoring of prototype situations by hydrographic surveys for several months after seawall installation.

\section{Design of Seawall}

According to Kamphuis (2020) design considerations for seawalls are: overtopping water spray that result in accelarated corossion, physical barrier for wildlife shore movement and design of the ends of seawall.

Furthermore, seawalls can have variety of face shapes such as curved and stepped seawall. A curved face seawall is intended to adapt the effect and keep running up of huge waves while directing the stream far from the land being protected. As the stream strikes the wall, it is compelled to stream along the curving face and finally is discharged in a vertical direction, falling harmlessly back to the ground, or it is re-curved to splash back toward the ocean, the enormous wave strength that must be opposed and diverted require a gigantic structure with a satisfactory establishment. Wave reflections from the wall likewise request strong toe protection (Leatherman, 1984).

Stepped seawalls are designed to limit wave run up and overtopping by the hindering action of the stepped face on the advancing wave front. Although somewhat less massive than curvedface seawalls, the general design requirements for structural stability are the same for this kind of structure. It also found structure combines a massive, curved face with a fronting stepped section that incorporates the advantages of both of those kinds of seawalls.

\section{Seawall Structure}


This section considers a range of conventional revetment and seawall structures that are typically placed along shorelines to prevent erosion of the land area behind the wall. Erosion is a natural phenomona that transform sediment away to the sea by the wave or wind energy or drainage (Hastuti, 2012).

Firstly, Composite seawalls are walls that are formed from a number of different systems, such as concrete and rock armour, or geotextile bags and timber. Secondly, Seabees are an example of a segmented unit seawall. Seabees are pattern-placed hexagonal interlocking units. Lastly, Sand filled geo textile bag seawall. These are often known as GSC (geosynthetic sand containers). GSC's behave very differently to concrete or rock armour units both due to their flexibility and lower specific gravity, and design guidance is still being developed (Dassanayake \& Oumeraci, 2012).

\section{Advantages and Disadvantages}

This structure has many different designs; it can be used to protect a cliff from wave attack and improve slope stability and it can also dissipate wave energy on sandy coasts. According to Prasetya (2006). The disadvantages of this structure are; (1) It creates wave reflections and promotes sediment transport offshore; (2) Scour occurs at the toes of eroded beaches; (3) It does not promote beach stability; (4) It should be constructed along the whole coastline; if not, erosion will occur on the adjacent coastline.

Dickinson (1971) explores more the disadvantages of seawall. A riprap seawall for instance employs a wide gravity supported base with the sides of the wall angling inwardly to the top. Materials for a riprap seawall may not be available and it is not watertight. Its costs are high and because of the angling sidewalls it is not possible to tie a boat alongside. The expert believe that seawalls cause erosion. However, seawalls are almost only built on eroding shorelines. Experts had explained the clear fact of passive erosion after the seawall development. Larson (2011)provides a vivid historical account converse of the statement is definitely true erosion can cause seawalls. Moreover, Barnett (1987) conducted a comprehensive set of wave tank measurements of beater profile response to a vertical seawall and found that the additional storm-induced scour volume at the base of the wall was approximately 60 percent of the upland erosion that would have occurred had the seawall not been present.

Griggs et al. (1997) examined seawall behavior in Monterey Bay. California, where the littoral drift rate is high and the seasonal fluctuations in the beach profile are large. Furthermore. for this study site, they found no net erosion induced by the seawall. The lack of seawall impact at this site is likely due to the extremely large longshore sediment transport that overwhelms any seawall effect.

\section{Application}

\section{Bangladesh Coastal Protection Project}

The Coastal Protection Project has been implemented in some area in Bangladesh. There is a major social impact when a large labour force (almost exclusively male) is brought into the polder and camps are established for this labour to live in over several years. There will be strains on the social fabric while there will be also employment business opportunities in providing goods and services to the project and to the labour force. There will be disruption of settlements and agricultural activity by the land taken temporarily to service the contractors' activities and additional land that is acquired permanently for embankment retirement and resectioning. The necessary eviction of embankment settlers - at least for the period when the 
embankment is being re-sectioned is a very serious matter that had to be handled with sensitivity (Islam, 1999).

\section{Seawall in Capital City of Samoa}

Lawson (2011)has explore the benefit of the seawall in an island state. The building of seawalls also has social and economic implications, which are essential to understand as well. There are, however, downsides to seawalls. Seawalls are thought to be particularly detrimental to beaches, which are an important resource for Samoa for both sand mining and tourism.

\section{Emergency seawall in West Sumatera}

Mulyani (2018) explained that there are a middle level of public participation to build a emergency seawall in Ulakan Beach, Padang Pariaman, West Sumatera. Coastal community has follow the model of sand bag to make an emergency seawall. They have collaborate with the village administration since they also have been impacted of the abrasion process.

\section{Methods}

\section{Research Design}

A mix method applied to this study.A set of questionnare is used as quantitative instrument and a structured interview for the qualitative instrument. An accurate evaluation will be resulted by adopting both methods.

The researcher decides to use method realizing the importance of primary data Since only a limited study on this matter has been published. The exploratory analysis from qualitative method will explore more information from the related person. The data then will be supported numerically by sistematic sampling to represent the respondents which related to the impact of seawall development. An exploratory descriptive research design had been chosen because it would conclusively describe the characteristics and state-of-the-art of the population under study.

\section{Data Collection}

The population of this study comprised of 1237 households and more than $30 \%$ involve in fishery activity and the rest were civil sector, agriculture and jobless. Based on Krejcie and Morgan sample size determination table, the minimum respondent is 293 respondents. Respondent will be choosen based on simple random sampling. A set of questionnaires was developed, covering as many as possible the items that might point to achieving the objectives of the study

Qualitative approach also used to collect primary data. A structured interview has been prepared to gather information about the impact of the seawall development. Some stakeholders will be asked related to this matter. Secondary Data will be collected from certain reliable sources were found to be most useful for this study.

\section{Data Analysis}

Collected data will be analyzed to find the impact of seawall development to fishermen community. Qualitative Data will be analyze using content analysis. Three main steps are followed for data presentation that are editing, coding and entry of data into appropriate software for analysis purpose. Following these steps is of greater importance for research as these steps help to convert the raw data into clasified form more accureately. For this purpose, Statitistical Package for Social Science (SPSS) Version 24 was used. 
Another important step in data analysis is to determine the reliability and validity of the data as it ensures the accuracy and concistency of the results. For testing the internal concistency of the items on each scale, Cronbach's Alpha was used and the result indicating that the instrumen is reliable.

Table 1. Reliability Test

\begin{tabular}{|l|c|c|}
\hline \multicolumn{1}{|c|}{ Variable } & Cronbach Alpha & No. of Items \\
\hline Fishery Activity Change & 0.906 & 8 \\
\hline Non-Fishery Activity Impact & 0.203 & 17 \\
\hline
\end{tabular}

The quantitative data collected were analysed using descriptive statistics. Statistical analysis using cross tabulation and chi-square with $95 \%$ confidence interval was used. Descriptive analysis using tables and chart was done to analyse the responses of respondents towards the study variables. Cross tabulation was conducted to find out the perceptual difference among the respondent categories using demographic variables. Chi-square is used to test the relationship between the backgrounds of the respondents (demography, educational background, age and occupation of respondents) and their perception to social and physical impact of the seawall development.

\section{Results and Discussion}

\section{Impact of Seawall Development in Pambusuang VIllage}

\section{Fishermen Activity Change}

Table 2. Fishermen Activity Change Questionnare Result

\begin{tabular}{|l|c|c|c|c|c|}
\hline \multicolumn{1}{|c|}{ Question } & SD & D & N & A & SA \\
\hline $\begin{array}{l}\text { Fishermen has a problem to dock } \\
\text { their ship }\end{array}$ & $3 \%$ & $26.7 \%$ & $1.3 \%$ & $25.7 \%$ & $43.3 \%$ \\
\hline $\begin{array}{l}\text { Fishermen dock their ship in the other } \\
\text { place }\end{array}$ & $1.7 \%$ & $31.7 \%$ & $2.7 \%$ & $23 \%$ & $41 \%$ \\
\hline $\begin{array}{l}\text { Fishermen spend extra money for } \\
\text { dock fees }\end{array}$ & $11.3 \%$ & $59 \%$ & $0 \%$ & $5.3 \%$ & $24.3 \%$ \\
\hline $\begin{array}{l}\text { Fishermen spend more for traveling } \\
\text { from dock place }\end{array}$ & $4.3 \%$ & $26.3 \%$ & $2.3 \%$ & $30.3 \%$ & $36.7 \%$ \\
\hline $\begin{array}{l}\text { Ship was mouldy due to submerged } \\
\text { in the water }\end{array}$ & $3.3 \%$ & $21.3 \%$ & $5.7 \%$ & $24 \%$ & $45.7 \%$ \\
\hline $\begin{array}{l}\text { Fishermen spend more for ship } \\
\text { maintenance }\end{array}$ & $4.7 \%$ & $19.7 \%$ & $7 \%$ & $20 \%$ & $48.7 \%$ \\
\hline $\begin{array}{l}\text { Fishermen incomes decrease because } \\
\text { of docking problem }\end{array}$ & $1.7 \%$ & $38.3 \%$ & $9.3 \%$ & $15.3 \%$ & $35.3 \%$ \\
\hline $\begin{array}{l}\text { Fishermen stop fishing because of } \\
\text { dock problem }\end{array}$ & $3.3 \%$ & $40.7 \%$ & 16.3 & $8.3 \%$ & $31.3 \%$ \\
\hline
\end{tabular}

Majority of the respondent agree that development of seawall create difficulties to the fishermen to dock their ship. Consequently, fishermen went to the other village to dock their ship there and burden for some transportation and docking cost

Contrary to the majority of the respondent, an NGO activist said that, some fishermen at least have to donate to the local mosque on the other docking place area. He explain, the resident of the adjacent village to Pambusuang village never ask for any payment to Pambusuang fishermen on their village, since most of them also have a relativeness and there is no one 
having the ownership on the coastal area. No one have an ownership on this resource that means everyone can use it and take advantages from this area. (Acheson, 1989)

While some of fishermen decided to dock their place in front of the seawall rather than to dock their ship on the sloping and sandy beach in other place, those fishermen faced problem about their ship. The impact of this process such as leaked boat, imbalance, decrease of speed and increased fuel consumption for motorboat

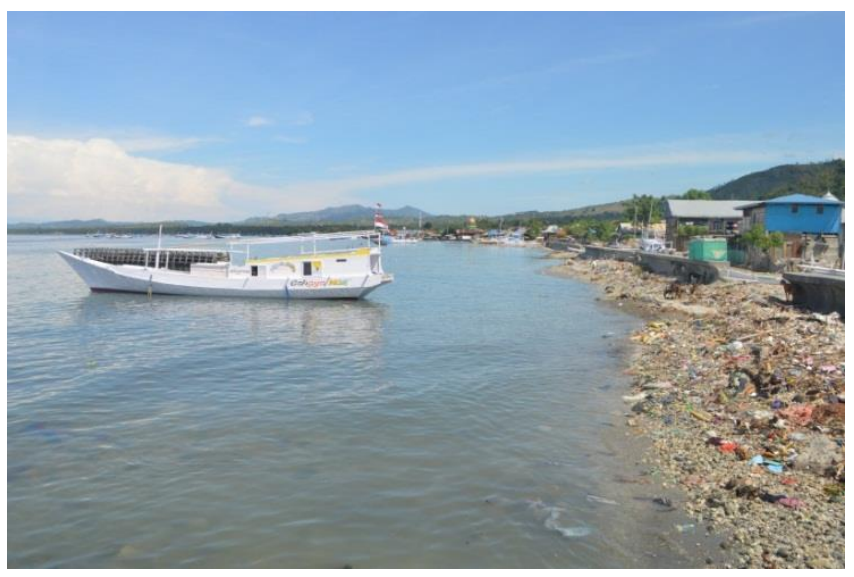

Figure 2. Docking in front of the seawall

More than a-third of the respondent strongly agree that the seawall development is related to the income decrease of the fishermen. The last question about the fishermen activity change is about fishermen decision to stop fishing after some difficulties that caused by seawall development. $56.3 \%$ of the respondents, believe that fishermen did not stop fishing as the impact of the docking problem only.

\section{Non-Fishery Activity Impact}

\section{Positive Impact of Seawall Development}

Table 3. Positive Impact of Seawall Development Questionnare Result

\begin{tabular}{|l|c|c|c|c|c|}
\hline \multicolumn{1}{|c|}{ Question } & SD & D & N & A & SA \\
\hline Seawall halt the shoreline erosion & $11.7 \%$ & $8.7 \%$ & $3.0 \%$ & $26.7 \%$ & $50.0 \%$ \\
\hline $\begin{array}{l}\text { Seawall prevent saline water intrusion to } \\
\text { human settlements }\end{array}$ & $1.7 \%$ & $5.7 \%$ & $6.0 \%$ & $28.3 \%$ & $58.3 \%$ \\
\hline $\begin{array}{l}\text { Seawall protect other infrastructure from wave } \\
\text { intrusion }\end{array}$ & $0 \%$ & $10.7 \%$ & $8.3 \%$ & $23.3 \%$ & $57.7 \%$ \\
\hline Seawall protect village from tidal flood & $6.7 \%$ & $14.7 \%$ & $8.0 \%$ & $40.7 \%$ & $30.0 \%$ \\
\hline $\begin{array}{l}\text { Seawall construction make the beach visually } \\
\text { more beautiful }\end{array}$ & $10.0 \%$ & $5.0 \%$ & $15.0 \%$ & $23.3 \%$ & $46.7 \%$ \\
\hline $\begin{array}{l}\text { The cap of the seawall provide accessible place } \\
\text { to walk, jog or sit }\end{array}$ & $17.3 \%$ & $8.0 \%$ & $6.3 \%$ & $23.3 \%$ & $45.0 \%$ \\
\hline $\begin{array}{l}\text { The carpenter income increase since seawall } \\
\text { constructed }\end{array}$ & $6.3 \%$ & $22.7 \%$ & $6.3 \%$ & $36.7 \%$ & $28.0 \%$ \\
\hline
\end{tabular}

Most of the respondent agreed that seawall structure halt the erosion on the shoreline and protect from tidal flood. $67 \%$ of the respondent believe that those curved seawall has succesfully reflect the wave and preventing wave energy to move sand away to the sea. Head of village explained that before village administration accepted the development project, he 
has got the agreement of the vilagers especially who live adjacent to the shoreline. He add that those villagers has been treathen by the wave attack since many years ago.

Furthermore, $70 \%$ of the respondent believe that development of seawall make the beach more beautiful. The development of seawall also give other benefit to the villagers. They used the seawall as relaxation place. Almost two third of the respondent believe that seawall cap is a one of the comfort place to sit in the early morning or in the evening. While the fishermen income has been decreased, the carpenter income has been increase. 194 of 300 respondent believe that since the government construct the seawall, the carpenter gain more profit from fishermen.

\section{Negative Impact of seawall development}

Table 4. Negative Impact of Seawall Development Questionnare Result

\begin{tabular}{|l|c|c|c|c|c|}
\hline \multicolumn{1}{|c|}{ Question } & SD & D & N & A & SA \\
\hline $\begin{array}{l}\text { Seawall construction made a conflict between } \\
\text { pro and contra villagers }\end{array}$ & $3.3 \%$ & $20.0 \%$ & $10.0 \%$ & $13.3 \%$ & $53.3 \%$ \\
\hline $\begin{array}{l}\text { Seawall create standing waves that intensifying } \\
\text { erosion in front of them }\end{array}$ & $8.3 \%$ & $47.3 \%$ & $19.7 \%$ & $14.7 \%$ & $10.0 \%$ \\
\hline Erosion may be accelerated on adjacent shores & $5.0 \%$ & $11.7 \%$ & $10.3 \%$ & $24.7 \%$ & $48.3 \%$ \\
\hline Seawall detrimental to the beaches & $31.7 \%$ & $36.3 \%$ & $9.0 \%$ & $8.0 \%$ & $15.0 \%$ \\
\hline Seawall make the river flow inundated & $12.0 \%$ & $19.0 \%$ & $1.3 \%$ & $46.3 \%$ & $21.0 \%$ \\
\hline $\begin{array}{l}\text { Seawall make beach look unnatural or } \\
\text { unsightly }\end{array}$ & $25.0 \%$ & $19.7 \%$ & $6.0 \%$ & $25.7 \%$ & $23.7 \%$ \\
\hline Seawall restrict access to the beach & $36.7 \%$ & $38.0 \%$ & $6.3 \%$ & $10.0 \%$ & $9.0 \%$ \\
\hline $\begin{array}{l}\text { Seawall construction create Impoundment or } \\
\text { placement loss }\end{array}$ & $40.0 \%$ & $30.0 \%$ & $11.7 \%$ & $5.0 \%$ & $13.3 \%$ \\
\hline $\begin{array}{l}\text { The number of towing man is decrease due to } \\
\text { development of seawall }\end{array}$ & $8.3 \%$ & $45.3 \%$ & $11.0 \%$ & $8.3 \%$ & $27.0 \%$ \\
\hline Seawall damage the natural life habitat & $10.0 \%$ & $15.7 \%$ & $13.7 \%$ & $18.0 \%$ & $42.7 \%$ \\
\hline
\end{tabular}

Seawall development resulting some negative impact. Ten question has been asked to the respondent to understand community perception on those impact. The statement about seawall development made conflict between pro and contra has been tested and the result shows twothird of the respondent agreed that the different perception of the seawall development lead to disharmony among the villagers.

Most people said that seawall development impact is the acceleration of erosion on adjacent shore, inundated river flow, the unnatural view of beach and damage of natural habitat. While disagreement has been voiced to statement about seawall become a clear border between upland and the sea, seawall construction acquisite villagers land and towing man has been decreased since the the contruction of the seawall.

The NGO activist explained that Bala Village shoreline become the victim of the Pambusuang seawall. The wave energy that has been reflected by the seawall was forwarded to the Bala Village shoreline. They also explain that most villagers consider river as their drainage system that flow to their sewer to the sea. When the river or drainage has been fulfilled by garbage, sloping and sandy beach is very helpful to absorp water run off especially in a heavy rain. 
The Corelation between Demographic Background and Opinion about Impact of Seawall Development

\section{Crosstabulations Analysis of Fishermen Activity Change}

Table 5. Crosstabulations analysis result of fishermen activity change with the demographic background of Respondent

\begin{tabular}{|c|c|c|c|c|c|c|}
\hline Question & Age & Sex & Education & Occupation & Income & $\begin{array}{c}\text { House } \\
\text { Location }\end{array}$ \\
\hline $\begin{array}{l}\text { Fishermen has a } \\
\text { problem to dock } \\
\text { their ship }\end{array}$ & $\begin{array}{c}- \\
(0.063)\end{array}$ & $\begin{array}{c}\mathrm{x} \\
(0,000)\end{array}$ & $\begin{array}{c}x \\
(0,000)\end{array}$ & $\begin{array}{c}\mathrm{x} \\
(0,000)\end{array}$ & $\begin{array}{c}\mathrm{x} \\
(0,000)\end{array}$ & $\begin{array}{c}\mathrm{x} \\
(0,000)\end{array}$ \\
\hline $\begin{array}{l}\text { Fishermen dock their } \\
\text { ship in the other } \\
\text { place }\end{array}$ & $\begin{array}{c}\mathrm{x} \\
(0,000)\end{array}$ & $\begin{array}{c}- \\
(0,200)\end{array}$ & $\begin{array}{c}x \\
(0,000)\end{array}$ & $\begin{array}{c}x \\
(0,000)\end{array}$ & $\begin{array}{c}\mathrm{x} \\
(0,000)\end{array}$ & $\begin{array}{c}\mathrm{x} \\
(0,000)\end{array}$ \\
\hline $\begin{array}{l}\text { Fishermen spend } \\
\text { extra money for } \\
\text { dock fees }\end{array}$ & $\begin{array}{c}\mathrm{x} \\
(0,000)\end{array}$ & $\begin{array}{c}x \\
(0,000)\end{array}$ & $\begin{array}{c}x \\
(0,000)\end{array}$ & $\begin{array}{c}x \\
(0,000)\end{array}$ & $\begin{array}{c}x \\
(0,000)\end{array}$ & $\begin{array}{c}\mathrm{x} \\
(0,001)\end{array}$ \\
\hline $\begin{array}{l}\text { Fishermen spend } \\
\text { more for treveling } \\
\text { from dock place }\end{array}$ & $\begin{array}{c}\mathrm{x} \\
(0,000)\end{array}$ & $\begin{array}{c}\mathrm{x} \\
(0,000)\end{array}$ & $\begin{array}{c}\mathrm{x} \\
(0,000)\end{array}$ & $\begin{array}{c}\mathrm{x} \\
(0,000)\end{array}$ & $\begin{array}{c}\mathrm{X} \\
(0,000)\end{array}$ & $\begin{array}{c}\mathrm{x} \\
(0,024)\end{array}$ \\
\hline $\begin{array}{l}\text { Ship was moldy due } \\
\text { to submerged in the } \\
\text { water }\end{array}$ & $\begin{array}{c}\mathrm{x} \\
(0,000)\end{array}$ & $\begin{array}{c}x \\
(0,000)\end{array}$ & $\begin{array}{c}\mathrm{x} \\
(0,000)\end{array}$ & $\begin{array}{c}\mathrm{x} \\
(0,000)\end{array}$ & $\begin{array}{c}\mathrm{x} \\
(0,000)\end{array}$ & $\begin{array}{c}\mathrm{x} \\
(0,000)\end{array}$ \\
\hline $\begin{array}{l}\text { Fishermen spend } \\
\text { more for ship } \\
\text { maintenance } \\
\end{array}$ & $\begin{array}{c}\mathrm{x} \\
(0,000)\end{array}$ & $\begin{array}{c}x \\
(0,000)\end{array}$ & $\begin{array}{c}x \\
(0,000)\end{array}$ & $\begin{array}{c}x \\
(0,000)\end{array}$ & $\begin{array}{c}\mathrm{x} \\
(0,000)\end{array}$ & $\begin{array}{c}\mathrm{x} \\
(0,000)\end{array}$ \\
\hline $\begin{array}{l}\text { Fishermen income } \\
\text { decrease because of } \\
\text { docking problem }\end{array}$ & $\begin{array}{c}\mathrm{x} \\
(0,000)\end{array}$ & $\begin{array}{c}\mathrm{x} \\
(0,001)\end{array}$ & $\begin{array}{c}\mathrm{x} \\
(0,000)\end{array}$ & $\begin{array}{c}\mathrm{x} \\
(0,000)\end{array}$ & $\begin{array}{c}\mathrm{x} \\
(0,000)\end{array}$ & $\begin{array}{c}\mathrm{x} \\
(0,002)\end{array}$ \\
\hline $\begin{array}{l}\text { Fishermen stop } \\
\text { fishing because of } \\
\text { dock problem }\end{array}$ & $\begin{array}{c}\mathrm{x} \\
(0,000)\end{array}$ & $\begin{array}{c}x \\
(0,000)\end{array}$ & $\begin{array}{c}x \\
(0,000)\end{array}$ & $\begin{array}{c}x \\
(0,000)\end{array}$ & $\begin{array}{c}\mathrm{x} \\
(0,000)\end{array}$ & $\begin{array}{c}\mathrm{x} \\
(0,000)\end{array}$ \\
\hline
\end{tabular}

Note: $\mathrm{x}=$ Significant corelation

- = Significant corelation

Its has been proved that the opinion about the difficulties to find a docking place after seawall development is not related to age of the respondents $(\mathrm{p}=0.063)$. While the other background of respondents show significant coreloation as shown in table 5.4. Crosstabulations between the opinion about difficulties of docking and the occupation of respondents shows that $77 \%$ fishermen who participated on this survey believe that the presence of seawall caused the docking problem.

Table 6. Crosstabulations between the opinion about difficulties of docking and the occupation of respondents

\begin{tabular}{|c|c|c|c|c|c|c|c|c|c|c|c|}
\hline \multirow{2}{*}{ Occupation } & \multicolumn{2}{|c|}{ SD } & \multicolumn{2}{|c|}{$\mathrm{D}$} & \multicolumn{2}{|c|}{$\mathrm{N}$} & \multicolumn{3}{|c|}{ A } & \multicolumn{3}{|c|}{ SA } & \multirow{2}{*}{ Total } \\
\cline { 2 - 13 } & $\mathrm{n}$ & $\%$ & $\mathrm{n}$ & $\%$ & $\mathrm{n}$ & $\%$ & $\mathrm{n}$ & $\%$ & $\mathrm{n}$ & $\%$ & \\
\hline Fishermen & 0 & $0 \%$ & 19 & $19 \%$ & 4 & $4 \%$ & 15 & $15 \%$ & 63 & $62 \%$ & 101 \\
\hline Merchant & 5 & $12 \%$ & 12 & $29 \%$ & 0 & $0 \%$ & 14 & $33 \%$ & 11 & $26 \%$ & 42 \\
\hline
\end{tabular}




\begin{tabular}{|c|c|c|c|c|c|c|c|c|c|c|c|}
\hline Carpenter & 0 & $0 \%$ & 10 & $38 \%$ & 0 & $0 \%$ & 2 & $8 \%$ & 14 & $54 \%$ & 26 \\
\hline Student & 0 & $0 \%$ & 4 & $17 \%$ & 0 & $0 \%$ & 6 & $26 \%$ & 13 & $57 \%$ & 23 \\
\hline Teacher & 0 & $0 \%$ & 7 & $47 \%$ & 0 & $0 \%$ & 2 & $13 \%$ & 6 & $40 \%$ & 15 \\
\hline Housewife & 0 & $0 \%$ & 8 & $40 \%$ & 0 & $0 \%$ & 9 & $45 \%$ & 3 & $15 \%$ & 20 \\
\hline Farmer & 0 & $0 \%$ & 6 & $32 \%$ & 0 & $0 \%$ & 7 & $37 \%$ & 6 & $32 \%$ & 19 \\
\hline Government & 0 & $0 \%$ & 8 & $50 \%$ & 0 & $0 \%$ & 5 & $31 \%$ & 3 & $19 \%$ & 16 \\
\hline Others & 4 & $14 \%$ & 4 & $14 \%$ & 0 & $0 \%$ & 10 & $34 \%$ & 11 & $38 \%$ & 29 \\
\hline Unemployed & 0 & $0 \%$ & 2 & $22 \%$ & 0 & $0 \%$ & 7 & $78 \%$ & 0 & $0 \%$ & 9 \\
\hline Total & 9 & $3 \%$ & 80 & $27 \%$ & 4 & $1 \%$ & 77 & $26 \%$ & 130 & $43 \%$ & 300 \\
\hline \multicolumn{3}{|c|}{ Pearson Chi Square } & \multicolumn{3}{|c|}{ Value $=98.219$} & \multicolumn{3}{|c|}{$\mathrm{df}=36$} & \multicolumn{3}{|c|}{$p=0.000$} \\
\hline
\end{tabular}

Head of village also support a disagreement to this statement he explained that existing seawall structure with some part of sloping gate for ship docking is enough for the current number of fishermen. He stressed that we have to understand that some fishermen docking their ship every day while the others docking every three or six month. The problem about limited parking area only happen several times in a year such as Maulidur Rasul Month (the third month of lunar calendar) and Idul Fitri Month (the tenth month of lunar calendar).

All the demographic background shows corelation with the perception of the need of fishermen to find their docking place outside Pambusuang Village . $70 \%$ of male respondent and $45 \%$ of female respondent support this statement. The agree voice also come from $75 \%$ respondents with no education background, $65 \%$ respondent who has finished their primary school and $67 \%$ of the respondent who has finished their secondary school. The disagreement also can be seen in every clasification of house location $(\mathrm{p}=0.001)$. The test result show significance corelation between the location of house and the expense for docking fee.
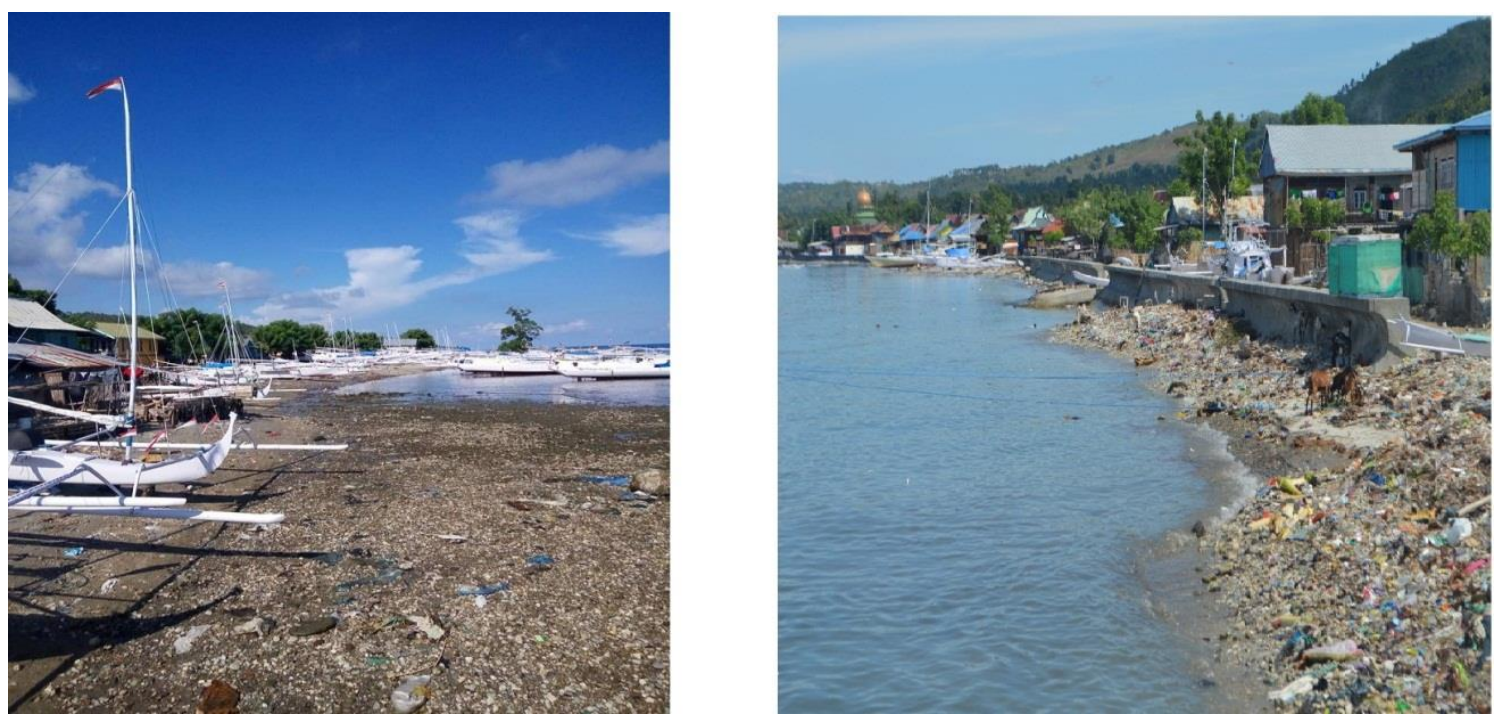

Figure 3. Before and After Seawall Development

Chi square test result indicates that background of respondents especially house location have siginificant relationship on the opinion about transport cost to the docking place $(\mathrm{p}=0.024)$. The highest percentage of agree respondent come from respondent who live more than $200 \mathrm{~m}$ from the shoreline. While, the highest disagreement percentage is come from respondents who live less than $20 \mathrm{~m}$ from the shoreline. (Table 6). 
Table 7. Crosstabulation Analysis between The spending for travel cost and house location of respondent

\begin{tabular}{|c|c|c|c|c|c|c|c|c|c|c|c|}
\hline \multirow{2}{*}{$\begin{array}{c}\text { House } \\
\text { Location }\end{array}$} & \multicolumn{2}{|c|}{ SD } & \multicolumn{2}{|c|}{ D } & \multicolumn{2}{|c|}{$\mathbf{N}$} & \multicolumn{2}{|c|}{$\mathbf{A}$} & \multicolumn{2}{|c|}{ SA } & \multirow[t]{2}{*}{ Total } \\
\hline & $\mathrm{n}$ & $\%$ & $\mathrm{n}$ & $\%$ & $\mathrm{n}$ & $\%$ & $\mathrm{n}$ & $\%$ & $\mathrm{n}$ & $\%$ & \\
\hline Less than & 0 & $0 \%$ & 20 & $29 \%$ & 2 & $3 \%$ & 33 & $47 \%$ & 15 & $21 \%$ & 70 \\
\hline $20-100$ & 5 & $4 \%$ & 30 & $26 \%$ & 3 & $3 \%$ & 33 & $29 \%$ & 44 & $38 \%$ & 115 \\
\hline $100-200$ & 3 & $6 \%$ & 13 & $26 \%$ & 2 & $4 \%$ & 11 & $22 \%$ & 21 & $42 \%$ & 50 \\
\hline $\begin{array}{l}\text { More than } \\
200\end{array}$ & 5 & $8 \%$ & 16 & $25 \%$ & 0 & $0 \%$ & 14 & $22 \%$ & 30 & $46 \%$ & 65 \\
\hline Total & 13 & $4 \%$ & 79 & $26 \%$ & 7 & $2 \%$ & 91 & $30 \%$ & 110 & $37 \%$ & 300 \\
\hline \multicolumn{3}{|l|}{ Pearson $\mathrm{Cl}$} & \multicolumn{3}{|c|}{ Value $=23.409$} & & \multicolumn{2}{|c|}{$\mathrm{df}=12$} & \multicolumn{3}{|c|}{$p=0.024$} \\
\hline
\end{tabular}

Crosstabulations analysis between educational qualification of the respondent with the opinion about increasing maintenance cost shows a significant corelation $(\mathrm{p}=0.023) .81 .81 \%$ of the respondents with primary education agree that docking problem cause higher maintenance cost. Almost half of the degree respondents have a contrary opinion to the majority of the respondents. They think the fishermen has spent maintenance fee to repainting their ship periodically. Sex $(p=0.001)$ and house location $(p=0.002)$ showing significant corelation with the respondent perception about the reduction of fishermen income. This statement was supported by $57 \%$ of male respondent and $34 \%$ of female respondent.

Table 8. Crosstabulation Analysis between statement that some fishermen stop fishing due to docking problem and the monthly income of respondents

\begin{tabular}{|c|c|c|c|c|c|c|c|c|c|c|c|}
\hline \multirow[t]{2}{*}{ Monthly Income } & \multicolumn{2}{|c|}{ SD } & \multicolumn{2}{|c|}{ D } & \multicolumn{2}{|c|}{$\mathbf{N}$} & \multicolumn{2}{|c|}{$\mathbf{A}$} & \multicolumn{2}{|c|}{$\mathbf{S A}$} & \multirow[t]{2}{*}{ Total } \\
\hline & $\mathbf{n}$ & $\%$ & $\mathbf{n}$ & $\%$ & $\mathbf{n}$ & $\%$ & $\mathbf{n}$ & $\%$ & $\mathbf{n}$ & $\%$ & \\
\hline No Income & 5 & $16 \%$ & 4 & $13 \%$ & 14 & $44 \%$ & 5 & $16 \%$ & 4 & $13 \%$ & 32 \\
\hline $1-300.000$ & 0 & $0 \%$ & 25 & $35 \%$ & 14 & $20 \%$ & 0 & $0 \%$ & 32 & $45 \%$ & 71 \\
\hline $300.000-1.000 .000$ & 0 & $0 \%$ & 20 & $31 \%$ & 15 & $23 \%$ & 10 & $15 \%$ & 20 & $31 \%$ & 65 \\
\hline $1.000 .000-2.000 .000$ & 5 & $5 \%$ & 48 & $47 \%$ & 6 & $6 \%$ & 5 & $5 \%$ & 38 & $37 \%$ & 102 \\
\hline $2.000 .000-3.000 .000$ & 0 & $0 \%$ & 5 & $50 \%$ & 0 & $0 \%$ & 5 & $50 \%$ & 0 & $0 \%$ & 10 \\
\hline$>3.000 .000$ & 0 & $0 \%$ & 20 & $100 \%$ & 0 & $0 \%$ & 0 & $0 \%$ & 0 & $0 \%$ & 20 \\
\hline Total & 10 & $3 \%$ & 122 & $41 \%$ & 49 & $16 \%$ & 25 & $8 \%$ & 94 & $31 \%$ & 300 \\
\hline \multicolumn{3}{|c|}{ Pearson Chi Square } & \multicolumn{3}{|c|}{ Value $=130.651$} & \multicolumn{3}{|c|}{$\mathrm{df}=20$} & \multicolumn{3}{|c|}{$\mathrm{p}=0.000$} \\
\hline
\end{tabular}

The impact of the seawall development seems to be push factor for some fishermen to stop fishing. Classifying the response based on respondents monthly income shows that disagreement mostly come from respondents who earn more than IDR 3,000,000 per month While the agreement to this statement mostly come from respondents who have mothly income less than IDR 300,000. The respondents with no income mostly have no opinion about this statement. 


\section{Impact of seawall development that not related to the fishermen activity}

\section{Positive Impact of Seawall Development}

Table 9. Crosstabulations analysis result of positive impact of seawall development with the demographic background of respondent

\begin{tabular}{|c|c|c|c|c|c|c|}
\hline Question & $\underset{\sim}{\infty}$ & 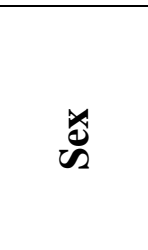 & : & 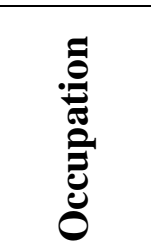 & 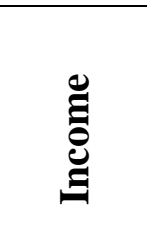 & 总 \\
\hline Seawall halt & $\begin{array}{c}- \\
(0.273) \\
\end{array}$ & $\begin{array}{c}\mathrm{x} \\
(0,008) \\
\end{array}$ & $\begin{array}{c}\mathrm{X} \\
(0,000) \\
\end{array}$ & $\begin{array}{c}\mathrm{x} \\
(0,000) \\
\end{array}$ & $\begin{array}{c}\mathrm{x} \\
(0,000) \\
\end{array}$ & $\begin{array}{c}x \\
(0,000)\end{array}$ \\
\hline $\begin{array}{l}\text { Seawall prevent saline w: } \\
\text { intrusion to human settler }\end{array}$ & $\begin{array}{c}- \\
(0,190)\end{array}$ & $\begin{array}{c}\mathrm{x} \\
(0,002)\end{array}$ & $\begin{array}{c}\mathrm{x} \\
(0,000)\end{array}$ & $\begin{array}{c}\mathrm{x} \\
(0,000)\end{array}$ & $\begin{array}{c}\mathrm{x} \\
(0,000)\end{array}$ & $\begin{array}{c}\mathrm{x} \\
(0,000)\end{array}$ \\
\hline $\begin{array}{l}\text { Seawall protect other } \\
\text { infrastructure from wave intrusion }\end{array}$ & $(0,042)$ & $\begin{array}{c}x \\
(0,048) \\
\end{array}$ & $\begin{array}{c}\mathrm{x} \\
(0,009) \\
\end{array}$ & $\begin{array}{c}\mathrm{x} \\
(0,000)\end{array}$ & $\begin{array}{c}\mathrm{x} \\
(0,000)\end{array}$ & $\begin{array}{c}x \\
(0,001)\end{array}$ \\
\hline $\begin{array}{l}\text { Seawall protect village from tidal } \\
\text { flood }\end{array}$ & $\begin{array}{c}- \\
(0,085)\end{array}$ & $\begin{array}{c}- \\
(0,084)\end{array}$ & $\begin{array}{c}\mathrm{x} \\
(0,000)\end{array}$ & $\begin{array}{c}\mathrm{x} \\
(0,000)\end{array}$ & $\begin{array}{c}\mathrm{x} \\
(0,000)\end{array}$ & $\begin{array}{c}\mathrm{x} \\
(0,024)\end{array}$ \\
\hline $\begin{array}{l}\text { Seawall construction make the } \\
\text { beach visually more beautiful }\end{array}$ & $\begin{array}{c}- \\
(0,055)\end{array}$ & $\begin{array}{c}- \\
(0,075)\end{array}$ & $\begin{array}{c}\mathrm{x} \\
(0,000)\end{array}$ & $\begin{array}{c}\mathrm{x} \\
(0,000)\end{array}$ & $\begin{array}{c}\mathrm{x} \\
(0,001)\end{array}$ & $\begin{array}{c}\mathrm{x} \\
(0,000)\end{array}$ \\
\hline $\begin{array}{l}\text { The cap of the seawall provide } \\
\text { accessible place to walk, jog or sit }\end{array}$ & $\begin{array}{c}\mathrm{x} \\
(0,014)\end{array}$ & $\begin{array}{c}\mathrm{x} \\
(0,005)\end{array}$ & $\begin{array}{c}\mathrm{x} \\
(0,000)\end{array}$ & $\begin{array}{c}\mathrm{x} \\
(0,000)\end{array}$ & $\begin{array}{c}\mathrm{x} \\
(0,000)\end{array}$ & $\begin{array}{c}\mathrm{x} \\
(0,000)\end{array}$ \\
\hline $\begin{array}{l}\text { The carpenter income increase } \\
\text { since seawall constructed }\end{array}$ & $\begin{array}{c}- \\
(0,607)\end{array}$ & $\begin{array}{c}\mathrm{x} \\
(0,002)\end{array}$ & $\begin{array}{c}\mathrm{x} \\
(0,000)\end{array}$ & $\begin{array}{c}\mathrm{x} \\
(0,000)\end{array}$ & $\begin{array}{c}\mathrm{x} \\
(0,000)\end{array}$ & $\begin{array}{c}\mathrm{x} \\
(0,002)\end{array}$ \\
\hline
\end{tabular}

Note: $\mathrm{x}=$ Significant corelation

$$
\text { - = No significant corelation }
$$

The researcher found the significant corelation between house location and the opinion about the seawall function to halt erosion $(\mathrm{p}=0.000)$. Most agreement come from respondent who live very close to the shoreline. The second question asked about the function of seawall to protect human settlement from water intrusion. The education background has a significant corelation with the opinion about statement above. The age of respondent does not have corelation with the opinion about the function of seawall to protect human settlement $(p=0.190)$

Table 10. Crosstabulation Analysis between The fucntion of seawall to protect human settlement and education background of respondents

\begin{tabular}{|c|c|c|c|c|c|c|c|c|c|c|c|}
\hline \multirow{2}{*}{ Education } & \multicolumn{2}{|c|}{ SD } & \multicolumn{2}{|c|}{ D } & \multicolumn{2}{|c|}{$\mathbf{N}$} & \multicolumn{2}{|c|}{$\mathbf{A}$} & \multicolumn{2}{|c|}{ SA } & \multirow{2}{*}{ Total } \\
\hline & $\mathbf{n}$ & $\%$ & $\mathbf{n}$ & $\%$ & $\mathbf{n}$ & $\%$ & $\mathbf{n}$ & $\%$ & $\mathbf{n}$ & $\%$ & \\
\hline $\begin{array}{l}\text { No } \\
\text { Education }\end{array}$ & 0 & $0 \%$ & 10 & $17 \%$ & 6 & $10 \%$ & 16 & $27 \%$ & 28 & $47 \%$ & 60 \\
\hline Primary & 5 & $5 \%$ & 0 & $0 \%$ & 5 & $5 \%$ & 24 & $24 \%$ & 65 & $66 \%$ & 99 \\
\hline Secondary & 0 & $0 \%$ & 7 & $7 \%$ & 7 & $7 \%$ & 25 & $26 \%$ & 59 & $60 \%$ & 98 \\
\hline Degree & 0 & $0 \%$ & 0 & $0 \%$ & 0 & $0 \%$ & 20 & $51 \%$ & 19 & $49 \%$ & 39 \\
\hline Others & 0 & $0 \%$ & 0 & $0 \%$ & 0 & $0 \%$ & 0 & $0 \%$ & 4 & $100 \%$ & 4 \\
\hline Total & 5 & $2 \%$ & 17 & $6 \%$ & 18 & $6 \%$ & 85 & $28 \%$ & 175 & $58 \%$ & 300 \\
\hline \multicolumn{3}{|c|}{ Pearson Chi Square } & \multicolumn{3}{|c|}{ Value $=49.408$} & \multicolumn{3}{|c|}{$\mathrm{df}=16$} & \multicolumn{3}{|c|}{$\mathrm{p}=0.000$} \\
\hline
\end{tabular}


The corelation between respondent age and the opinion about the function of seawall to protect other infrastructure $(\mathrm{p}=0.042) .112$ of 130 respondents who age between 30-39 years old believe the seawall has protected othe infrastructure such as road. The respondent also asked about the effectivenes of seawall to protect from tidal flood $74 \%$ fishermen that participated in this survey answered strongly agree and agree about this statement. Educational background influence the respondent opinion about protection from tidal flood $(0.000)$. The disagreement of the function of seawall to protect village from tidal wave mostly come from respondent who have no education background. The age $(\mathrm{p}=0.085)$ and the sex $(\mathrm{p}=0.084)$ of the respondent does not show any corelation to the statement

\section{Negative Impact of Seawall Development}

Table 11. Crosstabulations analysis result of poaitive impact of seawall development with the demographic background of respondent

\begin{tabular}{|c|c|c|c|c|c|c|}
\hline Question & Age & Sex & Education & Occupation & Income & $\begin{array}{c}\text { House } \\
\text { Location }\end{array}$ \\
\hline $\begin{array}{l}\text { Seawall construction } \\
\text { made a conflict } \\
\text { between pro and } \\
\text { contra villagers }\end{array}$ & $\begin{array}{c}\mathrm{x} \\
(0.000)\end{array}$ & $\begin{array}{c}- \\
(0.093)\end{array}$ & $\begin{array}{c}\mathrm{x} \\
(0.000)\end{array}$ & $\begin{array}{c}\mathrm{x} \\
(0.000)\end{array}$ & $\begin{array}{c}\mathrm{x} \\
(0.000)\end{array}$ & $\begin{array}{c}\mathrm{x} \\
(0.000)\end{array}$ \\
\hline $\begin{array}{l}\text { Seawall create } \\
\text { standing waves that } \\
\text { intensifying erosion } \\
\text { in front of them }\end{array}$ & $\begin{array}{c}\mathrm{x} \\
(0.000)\end{array}$ & $(0.064)$ & $\begin{array}{c}x \\
(0.000)\end{array}$ & $\begin{array}{c}\mathrm{x} \\
(0.000)\end{array}$ & $\begin{array}{c}\mathrm{x} \\
(0.000)\end{array}$ & $\begin{array}{c}\mathrm{x} \\
(0.000)\end{array}$ \\
\hline $\begin{array}{l}\text { Erosion may be } \\
\text { accelerated on } \\
\text { adjacent shores }\end{array}$ & $\begin{array}{c}\mathrm{x} \\
(0.002)\end{array}$ & $\begin{array}{c}- \\
(0.171)\end{array}$ & $\begin{array}{c}\mathrm{x} \\
(0.005)\end{array}$ & $\begin{array}{c}\mathrm{x} \\
(0.000)\end{array}$ & $\begin{array}{c}\mathrm{x} \\
(0.000)\end{array}$ & $\begin{array}{c}x \\
(0.001)\end{array}$ \\
\hline $\begin{array}{l}\text { Seawall detrimental } \\
\text { to the beaches }\end{array}$ & $\begin{array}{c}- \\
(0.170)\end{array}$ & $\begin{array}{c}\mathrm{x} \\
(0.000)\end{array}$ & $\begin{array}{c}\mathrm{x} \\
(0.000)\end{array}$ & $\begin{array}{c}\mathrm{x} \\
(0.000)\end{array}$ & $\begin{array}{c}\mathrm{x} \\
(0.000)\end{array}$ & $\begin{array}{c}\mathrm{x} \\
(0.024)\end{array}$ \\
\hline $\begin{array}{l}\text { Seawall make the } \\
\text { river flow inundated }\end{array}$ & $\begin{array}{c}\mathrm{x} \\
(0.022)\end{array}$ & $\begin{array}{c}- \\
(0.142)\end{array}$ & $\begin{array}{c}\mathrm{x} \\
(0.004)\end{array}$ & $\begin{array}{c}\mathrm{x} \\
(0.003)\end{array}$ & $\begin{array}{c}\mathrm{x} \\
(0.000)\end{array}$ & $\begin{array}{c}\mathrm{x} \\
(0.000)\end{array}$ \\
\hline $\begin{array}{l}\text { Seawall make beach } \\
\text { look unnatural or } \\
\text { unsightly }\end{array}$ & $\begin{array}{c}\mathrm{x} \\
(0.000)\end{array}$ & $(0.384)$ & $\begin{array}{c}\mathrm{x} \\
(0.000)\end{array}$ & $\begin{array}{c}\mathrm{x} \\
(0.000)\end{array}$ & $\begin{array}{c}\mathrm{x} \\
(0.000)\end{array}$ & $\begin{array}{c}\mathrm{x} \\
(0.000)\end{array}$ \\
\hline $\begin{array}{l}\text { Seawall restrict } \\
\text { access to the beach }\end{array}$ & $\begin{array}{c}\mathrm{X} \\
(0.028)\end{array}$ & $\begin{array}{c}- \\
(0.064)\end{array}$ & $\begin{array}{c}\mathrm{x} \\
(0.000)\end{array}$ & $\begin{array}{c}\mathrm{X} \\
(0.000)\end{array}$ & $\begin{array}{c}\mathrm{x} \\
(0.000)\end{array}$ & $\begin{array}{c}\mathrm{x} \\
(0.002)\end{array}$ \\
\hline $\begin{array}{l}\text { Seawall construction } \\
\text { create Impoundment } \\
\text { or placement loss }\end{array}$ & $\begin{array}{c}\mathrm{X} \\
(0.011)\end{array}$ & $\begin{array}{c}\mathrm{x} \\
(0.010)\end{array}$ & $\begin{array}{c}\mathrm{x} \\
(0.000)\end{array}$ & $\begin{array}{c}\mathrm{x} \\
(0.000)\end{array}$ & $\begin{array}{c}\mathrm{x} \\
(0.000)\end{array}$ & $\begin{array}{c}\mathrm{x} \\
(0.002)\end{array}$ \\
\hline $\begin{array}{l}\text { The number of } \\
\text { towing man is } \\
\text { decrease due to } \\
\text { development of } \\
\text { seawall }\end{array}$ & $\begin{array}{c}\mathrm{x} \\
(0.010)\end{array}$ & $\begin{array}{c}- \\
(0.311)\end{array}$ & $\begin{array}{c}\mathrm{x} \\
(0.000)\end{array}$ & $\begin{array}{c}x \\
(0.000)\end{array}$ & $\begin{array}{c}\mathrm{x} \\
(0.000)\end{array}$ & $\begin{array}{c}x \\
(0.002)\end{array}$ \\
\hline $\begin{array}{l}\text { Seawall damage the } \\
\text { natural life habitat }\end{array}$ & $\begin{array}{c}x \\
(0.041)\end{array}$ & $\begin{array}{c}- \\
(0.606)\end{array}$ & $\begin{array}{c}x \\
(0.000)\end{array}$ & $\begin{array}{c}\mathrm{X} \\
(0.000) \\
\end{array}$ & $\begin{array}{c}\mathrm{X} \\
(0.000) \\
\end{array}$ & $\begin{array}{c}\mathrm{x} \\
(0.002) \\
\end{array}$ \\
\hline
\end{tabular}

Note: $\mathrm{x}=$ Significant corelation

- = No significant corelation 
Chi Square test result show there is no corelation between sex of the respondent to the opinion that seawall development trigger conflict between the villagers $(p=0.093)$. The educational bakground of respondent influenced the repondents opinion about seawall development trigger conflict between pro-contra villager $(\mathrm{p}=0.000)$. More than three forth of respondent who only finished their primary education believe that the different opinion about seawall development make disharmony between villagers. Its followed by $74 \%$ of the respondent who only finished their secondary education and $70 \%$ of respondent who do not have any educational background.

Table 12. Crosstab analysis between educational qualification of respondent with the opinion about accelerated erosion on the adjacent beach

\begin{tabular}{|c|c|c|c|c|c|c|c|c|c|c|c|}
\hline \multirow{2}{*}{ Education } & \multicolumn{2}{|c|}{ SD } & \multicolumn{2}{|c|}{$\mathbf{D}$} & \multicolumn{2}{|c|}{$\mathbf{N}$} & \multicolumn{2}{|c|}{$\mathbf{A}$} & \multicolumn{2}{|c|}{$\mathbf{S A}$} & \multirow{2}{*}{ Total } \\
\hline & $\mathbf{n}$ & $\%$ & n & $\%$ & $\mathbf{n}$ & $\%$ & $\mathbf{n}$ & $\%$ & n & $\%$ & \\
\hline $\begin{array}{c}\text { No } \\
\text { Education }\end{array}$ & 2 & $3 \%$ & 10 & $17 \%$ & 10 & $17 \%$ & 16 & $27 \%$ & 22 & $37 \%$ & 60 \\
\hline Primary & 0 & $0 \%$ & 15 & $15 \%$ & 9 & $9 \%$ & 21 & $21 \%$ & 54 & $55 \%$ & 99 \\
\hline Secondary & 8 & $8 \%$ & 8 & $8 \%$ & 12 & $12 \%$ & 22 & $22 \%$ & 48 & $49 \%$ & 98 \\
\hline Degree & 5 & $13 \%$ & 2 & $5 \%$ & 0 & $0 \%$ & 15 & $38 \%$ & 17 & $44 \%$ & 39 \\
\hline Others & 0 & $0 \%$ & 0 & $0 \%$ & 0 & $0 \%$ & 0 & $0 \%$ & 4 & $100 \%$ & 4 \\
\hline Total & 15 & $5 \%$ & 35 & $12 \%$ & 31 & $10 \%$ & 74 & $25 \%$ & 145 & $48 \%$ & 300 \\
\hline \multicolumn{3}{|c|}{ Pearson Chi Square } & \multicolumn{3}{|c|}{ Value $=34.371$} & \multicolumn{3}{|c|}{$\mathrm{df}=16$} & \multicolumn{3}{|c|}{$p=0.005$} \\
\hline
\end{tabular}

Researcher found that educational background have siginificant relation to the opinion about accelerated erosion in adjacent shore $(\mathrm{p}=0.005)$. Table above shows distribution of the responses based on the educational qualification. $82 \%$ of degree respondent believe that seawall development in Pambusuang Village has been intensifying erosion on the beach adjacent to the pambusuang village. House location of the respondent show a siginificant corelation with statement about inundated river $(\mathrm{p}=0.000) .73 \%$ of the respondent who live very close to the shoreline believe that seawall structure is the main caused of inundated river flow.

The chi square result indicates a significant corelation between the age of the respondent with their opinion about unnatural view of the beach since seawall constructed $(p=0.000)$. The agrement to this statement only reach about $60 \%$ on three age range which are the oldest group, the youngest group and the 40-49 years old group. A balance opinion distribution can be found from 30-39 years old respondents, $45 \%$ of them agree and $47 \%$ disagree with the statement. The crosstabs analysis shows that there is significant corelation between the house location of respondent and the opinion about seawall create placement loss $(\mathrm{p}=0.001)$. Every clasisification of house distance to the shoreline contribute $55 \%-82 \%$ agreement about this statement. 


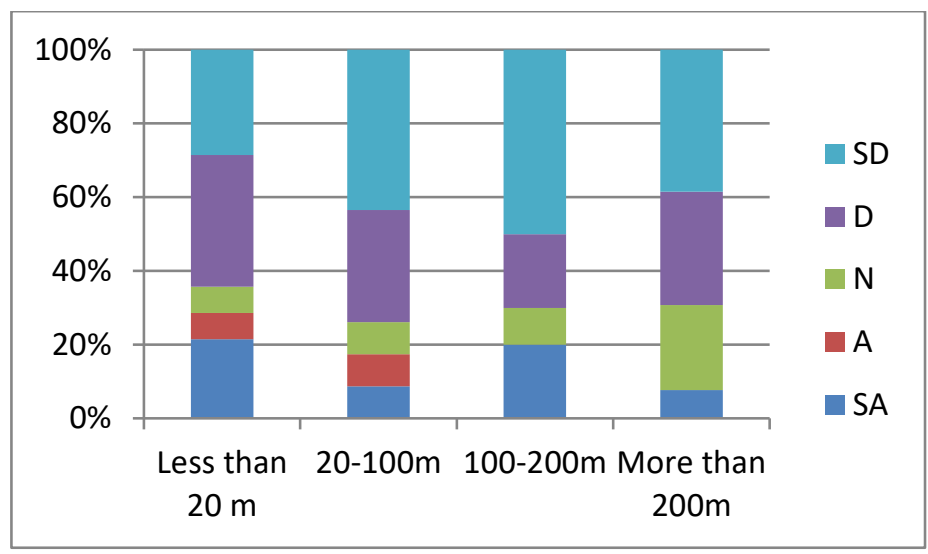

Figure 4. Respondent answer about seawall create placement loss based on house location of the respondent

\section{Community Responses to Address the Impact of Seawall Development}

The previous section clearly describe any change that related to fishermen after the development of seawall. The docking problem become the main problem that result on some other issues. A Master (the head of a fishermen group) explain that they already ask the developer to make sloping gate to help them to towing their ship to the upland

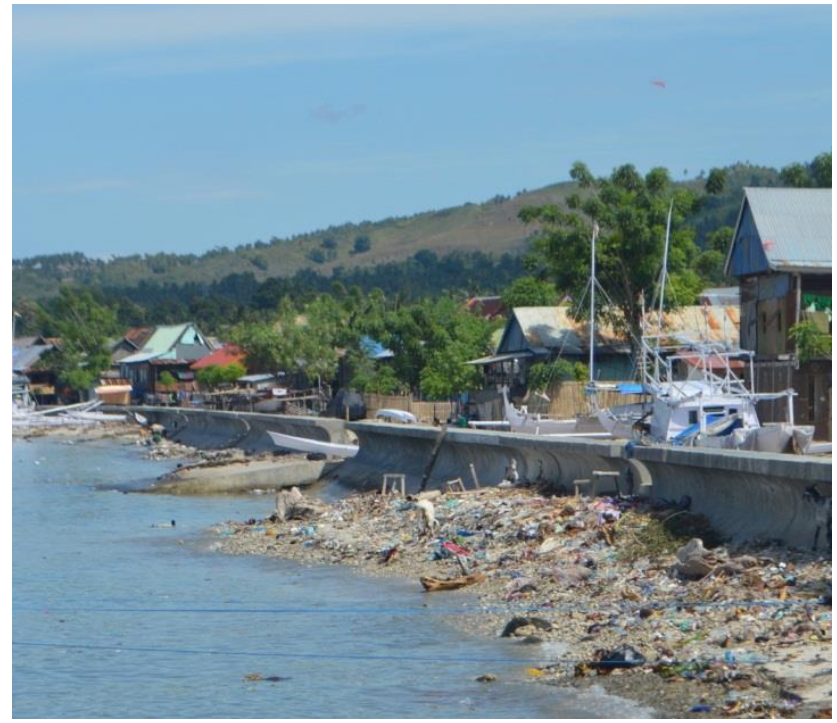

Figure 5. The Sloping Gate

The sloping gate has $8 \mathrm{~m}$ wide and the slope of $15 \%$. It has been used to towing the vessel to the upland behind the seawall. Mostly the vesel that towed trough this gate is small vessels that have $7 \mathrm{~m}$ length. The other strategy from the fishermen to address the docking problem is change their vessels to the smaller size. The masters and their fishermen on their group also has been adapted with the presence of the seawall.

Furthermore, since the government publish the plan to construct seawall in Pambusuang village, Villagers already responses with other alternatives of coastal protection structure. Some of them prefer a breakwater. The NGO Activist explain the detail of his suggestion about breakwater. He think that breakwater will not result on some negative impact as we explained above. Breakwater is a type of hard measurement constructed for the purpose of forming an artificial harbor with a basin so protected from the effect of waves as to provide safe berthing for fishing vessels. 


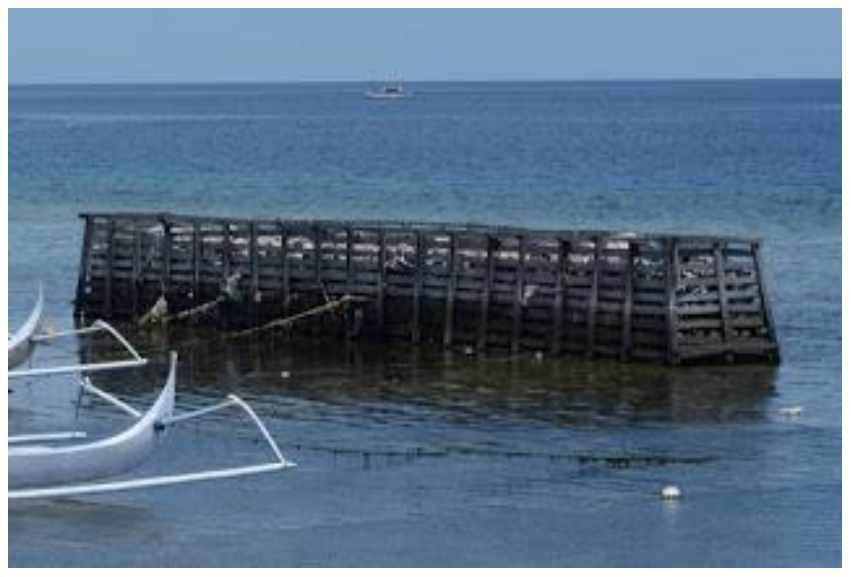

Figure 6. Breakwater

The Mandar bay in the southern part of Pambusuang village already have some breakwater since many years ago. He said, it has been built about $100 \mathrm{~m}$ when it built but now, some of them can be reach by walk when low tide occured. Some section of the breakwater have gap that used by the fishermen to access the coast. The benefit of developing breakwater away from the shoreline is to provide a calm area to tied up ship as well as the safe area for train young fishermen. It also caused accretion on the coast that provide more placement benefit for the villagers.

\section{Conclusion}

The seawall development that become main focus on this study is one of the type hard measurement to protect coastal area from the erosion. The seawall that has been developed in Pambusuang village is curved seawall with concrete structure. It's found that, the fishermen in Pambusuang Village have a difficulties to dock their ship. Most of the respondent from every type of job support this statement. Furthermore, this problem has led to some cost to the fishermen such as travel cost and docking fee cost. Moreover, they believe that seawall in their village has functioned properly to halt erosion, prevent saline water intrusion to human settlement, protect other infrastructure from the destructive wave energy and the protect from tidal flood. The other benefit of the seawall is the adding the aestethical value of the beach as well as the relaxation area. On the other hand, respondent also agree that seawall development has resulted some negative impact that are not related to the fishery activity such as inundated river flow and damaging natural habitat. Community especially the fishermen has adapated with the impact of the seawall condition. They are utilizing the exist sloping gate that has been made between the seawall to dock the smaller ship. Overall, we conclude that some difficulties and benefit has been proved felt by the fishermen community in Pambusuang Village. Some of them has been addressed by adapting the existing infrastructure and fishery technology.

\section{Recommendation}

Researcher recommends that government should conduct a participatory development approach to find the best alternative to protect the coastal area before start any construction. The people should be represented based on their interest equally on the form of development. The community itself, should start to give serious attention to any kind of development.

\section{References}

Acheson, J. M. (1989). Management of common-property resources. Economic Anthropology, $351-378$. 
Baba, M., \& Thomas, K. V. (1987). Performance of seawall with a frontal beach. In Coastal Sediments' 87. American Society of Civil Engineers, 1051-1061.

Barnett, M. R. (1987). Laboratory study of the effects of a vertical seawall on beach profile response. Coastal and Oceanographic Engineering Department. In Coastal and Oceanographic Engineering Department.

Dassanayake, D. T., \& Oumeraci, H. (2012). Engineering Properties of Geotextile Sand Containers and Their Effect on Hydraulic Stability and Damage Development of LowCrested / Submerged Structures. The International Journal of Ocean and Climate Systems, 3(3), 135-150. https://doi.org/10.1260/1759-3131.3.3.135

Dean, R.G. and Dalrymple, R. . (2002). Coastal Processes with Engineering Applications. Cambridge University Press.

Fadlan, A. (2015). Analisis Dampak Pembangunan Breakwater terhadap Perubahan Garis Pantai. Universitas Diponegoro.

Griggs, G., Tait, J., Moore, L., Scott, K., Corona, W., \& Pembrook, D. (1997). Interaction of searwalls and beaches: Eight years of field monitoring, Monterey bay, California. January, 1-34.

Hastuti, A. W. (2012). Coastal Vulnerability Analysis of Sea Levels Threats in SOuth Yogyakarta. June, 90. https://doi.org/10.13140/RG.2.1.3913.9444

Islam, M. N. (1999). Embankment erosion control: towards cheap and simple practical solutions for Bangladesh. Proceedings of the Second International Conference on Vetiver. Office of the Royal Development Projects Board, Bangkok, 1, 307-321.

Kamphuis, J. W. (2020). Introduction to coastal engineering and management (3rd ed.). World Scientific Publishing Co Inc.

Larson, E. (2011). Isaac's storm: A Man, a Time, and the Deadliest Hurricane in History. Vintage Books.

Lawson, S. (2011). Seawalls in Samoa : A Look at Their Environmental, Social and Economic Implications. ISP Collection. Paper 1058.

Leatherman, S. P. (1984). Coastal Geomorphic Responses to Sea Level Rise: Galveston Bay, Texas. Greenhouse Effect and Sea Level Rise, 151-178. https://doi.org/10.1007/9781-4684-6569-3_5

Magoon, O. T., Edge, B. L., \& Stone, K. E. (2001). The impact of anthropogenic activities on coastal erosion. Coastal Engineering 2000, 3934-3940.

Mulyani, H., \& Edial, H. (2018). Partisipasi Masyarakat dalam Menanggulangi Abrasi Pantai Ulakan di Nagari Manggopoh Palak Gadang Kecamatan Ulakan Tapakis. Buana, 3(3), $451-465$.

Necipoğlu, N. (2001). Byzantine Constantinople: monuments, topography and everyday life.

Prasetya, G. (2006). The Role of Coastal Forest and Trees in Combating Coastal Erosion What is Coastal Erosion? Proceedings of the Regional Technical Workshop on Coastal Protection in the Aftermath of the Indian Ocean Tsunami: What Role for Forest and Trees, August, 28-31.

Selvan, S. C., Kankara, R. S., Markose, V. J., Rajan, B., \& Prabhu, K. (2016). Shoreline change and impacts of coastal protection structures on Puducherry, SE coast of India. Natural 
Hazards, 1(83), 293-308.

Tarigan, M. S. (2010). Perubahan Garis Pantai Di Wilayah Pesisir Perairan Cisadane, Provinsi Banten. MAKARA of Science Series, 11(1), 49-55. https://doi.org/10.7454/mss.v11i1.242

USAEC. (1995). Engineering and Design. Design of Coastal Revetments, Seawalls, and Bulkheads 